2. Бурлаков В.Н. Индивидуальная профилактика правонарушений: проблемы и суждения// Вестник Ленинградского университета. Серия: Экономика. Философия. Право. 1982. № 23. С. 103-108.

3. Долгова А. И. Организация предупреждения преступности с учетом детерминации// Вопросы борьбы с преступностью. Вып. 47. 1988. C. $85-87$.

4. Голіна В. В. Попередження злочинності : лекція. Харків. 1994. $-40 \mathrm{c}$.

5. Голіна В.В. Кримінологічна профілактика злочинності: поняття, специфіка, структура, об’єкт запобіжного впливу. 2015. Вип. 130. C.145-154.

6. Криминология: Учебник. Под ред. д. ю. н. В. Н. Бурлакова, д. ю. н. Н. М. Кропачева. СПб. Питер. 2002. - 432 с.

7. Голіна В.В. Запобігання злочинності (теорія і практика). Харків. 2011. $120 \mathrm{c}$.

8. Литвинов О.М. Функціональний аналіз запобігання злочинам// Право і безпека. 2014. № 2 (53). С. 106-110.

9. Бандурка О.М., Литвинов О.М. Стратегія і тактика протидії злочинності: монографія. Харкв. 2012. 318 с.

DOI https://doi.org/10.30525/978-9934-588-92-1-76

\title{
ДО ПИТАННЯ ПРО КРОВАВУ ПОМСТУ У МОСКОВСЬКІЙ ДЕРЖАВІ ТА РОСІЙСЬКІЙ ІМПЕРІЇ У ПРАЦЯХ І. МАЛИНОВСЬКОГО
}

\author{
Матвійчук М. А. \\ аспірантка, \\ викладачка кафедри кримінально-правових дисциплін \\ Національного університету «Острозька академія» \\ м. Острог, Рівненська область, Україна
}

В древності, зазначав I. Малиновський, не було смертної кари в сучасному розумінні цього слова, в смислі покарання, що покладається з волі держави. Була помста, тобто відплата, яка здійснювалася руками приватної особи - потерпілим. Помста виражалася у посяганні на кривдника, зокрема, й у формі позбавлення його життя. Стверджуючи це, вчений виходив, за Арістотелем, з того, що людина це «суспільна 
тварина», оскільки умови життя та виживання, потреби тощо, особливо на зорі людства у них в принципі одинакові. Тваринам властиве відчуття злості та ненависті до ворога, тварини мстять за образу. Цей древній інститут, коли кожен був суддею у власній справі, тобто сам визначав характер посягання на нього, сам призначав за нього жорстоку кару i сам же приводив свій вирок до виконання, в первісному суспільстві був «доброчинним інститутом». Кровавий месник, сам не усвідомлюючи цього, стримував людей того часу від насильства і тим самим виконував свою частку обов'язку по спасінню свого народу від загибелі від таких же кровавих справ. Самозахист, самосуд тих часів був засобом, що сприяв вищому розвитку суспільних відносин [1, с. 4-8, 48-49].

Далі, зазначає I. Малиновський, в міру повторення окремих випадків помсти в людини поступово складається переконання, що мстити можна і треба. Так факт помсти перетворюється в право та обов'язок, - уже не дикий тваринний інстинкт, а право, санкціоноване юридичними, зокрема, звичаєвими нормами, і разом з тим у моральний та релігійний обов'язок, бо в древності право, мораль і релігія не виокремлювались. Так настає друга стадія самосуду. Люди переймаються свідомістю того, що мстити можна і треба, що образа може та неодмінно має бути відомщена [3, с. 189].

Так, ображений мусів помститися, а кривдник мусів понести відплату за свою вину, бо виконання помсти - славний, доблесний подвиг, а ухилення від нього, - ганебний проступок. Месниками виступали не лише скривджені, а й його родичі. Помста, таким чином, мала не лише характер кровавої в смислі кровопролитної, а й кровної в смислі помсти з боку родичів по крові. Так помста переходила від покоління до покоління [4, с. 52-53].

«Переживання» кровавої помсти як поодинокі іiі випадки ще мали місце й пізніше на теренах Київської Русі після іiі розпаду. У Великому князівстві Литовському, наприклад, ще в другій четверті XVI ст. в Литовському Статуті 1529 р. передбачався випадок, коли злочинець, засуджений до смертної кари, видавався потерпілому для того, щоби «он его вбил». Уставні грамоти московського періоду самосуд забороняють. Уже в одній 3 перших з найбільш ранніх грамот (Двінській) значилось: «А самосуд то, кто изывавъ с полисным, да отпуститъ и себе посул возметъ, а наместники доведаются, а опричь того самосуда нетъ» (ст. 6). Але не дивлячись на законодавче скасування помсти в XIII ст. вона зберігається в XIV і XV ст.ст.; в очах, наприклад, князів південно-східної Росії вона вважалась необхідною: син вважає священним обов'язком мстити за батька, брат за брата [1, с. 85$]$. 308 
Найважливішим явищем в історії соціального ладу в XVII ст. в Московській державі став гніт поміщицький над холопством i кріпосним селянством, гніт фінансовий, адміністративний і судовий над рештою трудового люду. Народ почав протестувати. Настали часи відродження кровавої помсти як тваринного інстинкту, самосуду, самоуправства, саморозправи [5, с. 181-182].

Одним з перших проявів народних соціальних заворушень на початку XVII ст. в Московській державі сталося на Сіверщині під проводом Хлопка Косолапого, шайка якого не обмежилася простими грабежами, а направилась прямо на Москву з метою знищити і престол, і бояр. Хлопка стратили в Москві, решту його людей повісили на деревах. Але те, що було лише намічено Хлопком Косолапим, виливається у певну програму, яка виконується, - здійснюються погроми сильних, багатих, тих, хто володарює: бунт під проводом Болотнікова, бунт під проводом Федора Красного, бунт під керівництвом Григорія Лапша...; Не припинялися заворушення народних мас i бунти й при царюванні Петра I. Подавлялися вони не менш жорстоко. Сам Петро I, наприклад, рубав голови стрільцям-бунтівникам 1698 р., та примушував підлеглих робити те ж саме. Страшний же вибух народної помсти відомий під назвою пугачовщини. Пугачов у своїх маніфестах проголошував себе істинним государем, малював прекрасну картину життя без кріпосного права тощо, для чого лише потрібно, закликав він, знищити ненависне минуле i сучасне, знищити усіх гнобителів і грабіжників народу. Гнобленні та ображені скористались випадком, щоби відомстити своїм соціальним ворогам і... відомстили. Згідно далеко неповних даних за пугачовщини було знищено 2791 дворянина, 237 священників з їх дружинами, 1037 унтер-офіцерів, різночинців та приказних службовців з їх дружинами i дітьми. 3 поміж них 666 чоловіків, жінок і дітей повісили, 384 забили до смерті, страждальницькою смертю замордували 251, застрелили 121, закололи 72, порубали 64, утопили дворянських немовлят 15 . В архівних матеріалах вказуються й інші способи вбивств: «задавлений на поясі», «проколота в горло та живіт списом», «утоплена в старій криниці й засипана землею», «живою кинута в палаюче багаття»... [1, с. 157-160].

Після приборкання пугачовщини настало відносне затишшя. За 20 років (1835-1854рр.), наприклад, відбулося (лише) 144 вбивства поміщиків і 29 вбивств управляючих. Вбивці уже каралися по суду, в тому числі каторгою з висланням в Сибір. Але на початку XX ст. в Російській імперії знову відродилися старовинні традиції кровавої помсти, і відродилися уже на грунті аграрних заворушень, революційного терору, чорносотенних погромів, а у відповідь - терору урядового у формі масових страт як по суду, так і без суду. Учений i 
тому, i іншому проявам кровавої помсти, здебільшого під час революційних подій 1905-1907 рр., присвячує другий випуск своєї праці «Кровава помста і смертні страти» (1909 р.)., оснований на 97 першоджерелах - додатках до праці [2, с. 278]. В цій праці I. Малиновський на конкретних прикладах демонструє жорстокість смертельної помсти селян поміщикам і управителям їх маєтків, помсту революціонерів-терористів російським імператорам i високопосадовцям, безжалісність кровавих чорносотенних, в том числі єврейських погромів, і не менш кровавих відповідей на них, жахливість урядового терору у формі розстрілів, повішання, інших форм саморозправи 3 боку держави та ії службових і посадових осіб щодо повстанців, протестантів, погромників, страйкуючих тощо [2, с. 3-159].

До речі, книга «Кровава помста і смертні кари» вченого викликала гучний резонанс по всій Росії та не була сприйнята урядом, через що I. Малиновський зазнав переслідувань. У 1912 p. професор був відсторонений від викладацької роботи, звільнений 3 Томського університету та засуджений Омським окружним судом на підставі пп. 3 і 4 ст. 129 Кримінального уложення, за «спонукання до невиконання законів» до «ув'язнення в тюрмі на один місяць без позбавлення прав або обмеження в правах». Працю «Кровава помста і смертні кари» суд постановив знищити. Від відбування покарання вченого тоді «спас» указ з приводу 300-ліття дому Романових (амністія), а книгу, наскільки це було можливим, знищили шляхом спалювання [7, с. 7-9].

Відродження кровавої помсти мало місце й на теренах Російської імперії в період революційних подій 1917 р., а пізніше під час революційного терору та громадянської війни. Вага революції, писав I. Малиновський вже за радянських часів, характеризується актами помсти; руйнування давнього ладу йде разом із помстою революціонерам або прихильників революції з боку тих, хто панував за давнього ладу, й помстою їм з боку революціонерів. Окрім того революціонери, ба навіть нейтральні особи, мусять, буває, вжити актів самосуду й розправи, себто помсти звичайних карних елементів, коли вони роблять замах на особу та майно, не боячись кари, бо давній порядок правний зруйновано, а новий іще не налагоджено. Наша революція не могла бути винятком. Акти такого роду помсти не могли не траплятися й у розпалі громадянської війни [8, с. 111-112].

Але випадки відродження старовинних традицій самосуду та пости можуть мати місце як виключні явища у внутрішньому житті культурних народів не лише під час бунтів і народних заворушень. Вони, зауважує вчений, можуть мати та мають місце у будь-який час $\mathrm{i}$ пояснюються станом сильного збудження, яке може охопити людину, 310 
яка стала жертвою, на іiї погляд, тяжкої образи [6, с. 13]. Наостанок, до давно пройдених часів самосуду та помсти повертає нас війна як останній, вищий спосіб, за допомогою якого вирішуються суперечки між державами, пише I. Малиновський на другому році Першої світової війни, учасницею якої була й Російська імперія. На війні противники підпорядковуються голосу мстивого відчуття, одні в меншому, інші в більшому ступені, легко переходять межу дозволеного та доцільного, легко здійснюють неприпустиме, несправедливе та жорстоке [6, с. 15-18].

\section{Література:}

1. I. Малиновскій Кровавая месть и смертныя казни. Выпуск I. Томскъ: Типо-литографія Сибирскаго Тов-ва Печатн. Дъла, 1908. С. 3.

2. Малиновскій I. Кровавая месть и смертныя казни. Выпуск II. Томскъ: Типо-литографія Сибирскаго Тов-ва Печатн. Дьла, 1909. 279 с.

3. Малиновскій I. А. Начальная страница изъ исторіи смертной казни (кровавая месть) // Записки Императорскаго Русскаго гнографическаго общества по отделению єтнографіи. Томъ XXXIV. I Сборникъ в честь семидесятилетия Григория Николаевича Потанина. 1909. C. $189-210$.

4. Докладъ I. А. Малиновскаго: «Кровавая месть и смертныя казни». Пренія по докладу // Труды юридическаго общества при Императорскомъ С-Петербургскомъ университетъ. Томъ I (19081909 г.). С-Петербургь: Типографія М. М. Стасюлевича, 1910. С. 51-70.

5. Малиновскій I. Лекціи по исторіи русскаго права. Издательство кооперативного т-ва «Единение» в Ростове на Дону, 1918. 488 с.

6. Малиновскій I. А. Война и судъ (по поводу юбилея судебной реформы 1864 года). Варшава: Типографія ВАршавскаго Учебного Округа, 1915. 19 с.

7. Попелюшко В. А. Иоанникий Алексеевич Малиновский (18681932) // Малиновский И. А. Кровавая месть и смертные казни / под ред. проф. В. А. Попелюшко. М.: Юрлитинформ, 2015. С. 7-9.

8. Малиновський О. О. Кара й засоби соціального захисту /Записки соціально-економічного відділу Української академії наук. Том IV. 1926. У Київі. С. 111-112. 